\title{
Et in Arcadia ego. Norwegian Dream jako mempleks norweskości
}

„Teksty z Ulicy. Zeszyt memetyczny” 2019, nr 20

Https://doi.org/10.31261/tzu.2019.20.06

\section{Streszczenie}

Autor ukazuje Norwegian Dream jako przekaz mający na celu tworzenie i utrzymanie norweskiego brandingu i zwraca uwagę na funkcjonowanie w tym przekazie typowych cech mempleksu, który określa mianem mempleksu norweskości. Autor traktuje Norwegian Dream jako narrację dotyczącą funkcjonowania norweskiego świata i bada morfologię memów wchodzących w skład mempleksu norweskości, zwracając uwagę na fakt, iż u podstaw sukcesu i popularności Norwegian Dream, leży mit arkadyjski rozumiany jako wszechobecna ludzka potrzeba życia w świecie, w którym panuje dobro, tolerancja i powszechne szczęście.

Słowa klucze:

Norwegia, Norweski Sen, branding, Arkadia, mempleks

\section{Et in Arcadia ego. Norwegian Dream as norwegian memplex}

\section{Summary}

The author describes Norwegian Dream, as a message with a purpouse of creating and maintaing Norwegian branding and gives a light to the functioning in this message of characteristic features of a memplex which can be defined as Norwegian memplex. The author treats Norwegian Dream as a narration concerning the functioning of Norwegian world and studies morphology of memes, including Norwegian memplex, highlighting the fact that success and popularity of Norwegian Dream lies in Arcadia myth, which is understood as universal, human need to live in a world where there is welfare, tolerance and happiness.

Keywords:

Norway, Norwegian Dream, branding, Arcadia, memplex 
I czyż nie narzuca sie podejrzenie, że gdyby „być nie byto
"do czegos”, a świat pozbawiony sensu, to nie tylko nigdy
nie zdotalibyśmy wyobrazić sobie, że jest inaczej, lecz nawet
pomyśleć nie bylibyśmy w stanie tego wtaśnie, że „być nie
jest w istocie „do czegos”, a świat pozbawiony sensu? Leszek Kołakowski

Próbowatem wrócić do raju Tadeusz Różewicz

\section{Mempleks norweskości...}

Kultura jest - między innymi - pytaniem człowieka o sens świata i sens bycia w świecie, pytaniem o adaptacje człowieka do świata i pytaniem o ludzką potrzebę dokonywania zmiany świata. Kultura jest - również - poszukiwaniem odpowiedzi na tak stawiane pytania. Kulturę stanowią - przede wszystkim - ludzkie wybory, dokonujące się wobec tych pytań i wobec poszukiwań odpowiedzi na te pytania, realizowane w określonej rzeczywistości i w określonym czasie. Interesujący nas czas to czas teraźniejszy, interesujące nas miejsce to współczesna Norwegia. Interesujące nas ludzkie wybory to wybory Norwegian Dream ${ }^{1}$.

Czym jest Norwegian Dream? A może należałoby zapytać: czym Norweski Sen nie jest? Odwołajmy się w tym miejscu do stwierdzeń Niny Witoszek:

W odróżnieniu od American Dream - jednego z najbardziej uwodzicielskich mitów współczesności - Norwegian Dream, znacznie mniej spektakularny, zasługuje na uwagę właśnie dlatego, że mówi nie o wyczynach gwiazdorskich milionerów i supermanów, lecz o ważności zwykłych ludzi, takich jak ty i ja².

Dalej Witoszek stwierdza: „W kategoriach mitycznych Norwegia jest radykalnym przeciwieństwem Ameryki”" Przypomnijmy, co jeszcze na ten temat pisała Nina Witoszek:

Taka właśnie jest Norwegia w XXI wieku - ostoja Europy na tle wzburzonych żywiołów, śpiewająca - jak chór z Titanica - w patriotycznym uniesieniu o cudzie istnienia, niezłomnie przy tym przekonana, że jest najlepszym z najlepszych światów. Cool $\mathcal{E}$ Crazy należy do gatunku filmów ojczyźnianych i przywołuje wszystkie obowiązujące obrazy i symbole norweskości: sztukę w przyrodzie i przyrodę w sztuce, człowieka jako dziecko natury, codzienny heroizm w walce o przetrwanie, socjalistyczne i seksualne fantazje zwyczajnie nadzwyczajnych obywateli. Ale, co najważniejsze, film przedstawia kwintesencje Norweskiego Snu: baśniowy scenariusz typu „z chłopa król”, w którym zwykli ludzie - czy to dosłownie, czy w przenośni - są ważni jak królowie ${ }^{4}$.

Autorka zauważa również:

Lecz w przeciwieństwie do Amerykanów - ukształtowanych przez wyobrażenia o bezgranicznej obfitości, sławie, miłości, władzy, szczęściu i wiecznej młodości -

${ }^{1}$ Na użytek tego tekstu traktuję jako tożsame określenia: Norwegian Dream i Norweski Sen i będę ich używać zamiennie.

${ }^{2}$ N. Witoszek, Najlepszy kraj na świecie. Pamflet, przeł. M. Kalinowski, Wołowiec 2017, s. 7.

${ }^{3}$ Tamże, s. 6.

${ }^{4}$ Tamże. 
Norwegowie są realistami: Norweski Sen dotyczy świata, w którym istnieją granice, umiar jest kluczem do wszystkiego, ludzie się starzeją, nikt nie jest doskonały, i gdzie w efekcie lepiej sprawdza się łagodna tyrania przeciętności niż akrobacje supermana. [...] Czy Norweski Sen jest odpowiedzią na ludzką tęsknotę za normalnością, bezpieczeństwem, spokojem i szczęściem? Jeżeli tak, to skąd czerpie on swą energię?5.

Jedną z możliwych odpowiedzi na tak zadane przez Ninę Witoszek pytania, jest opisanie Norwegian Dream jako mempleksu. Szczególnie wielość treści informacji kulturowych dotyczących Norwegian Dream i bezspornie infekcyjny charakter replikowania tych informacji skłaniają do stwierdzenia, że na przekaz Norweskiego Snu składają się byty wykazujące cechy organizmu żywego ${ }^{6}$, które są zdolne do replikacji i dziedzicznych zmienności, zdolne łączyć się w grupy i skłonne do ewolucji. Byty te określamy mianem memów, ich zbiory zaś to mempleksy.

Przestrzenie, w jakich funkcjonuja wspomniane memy/mempleksy to umysły ich nosicieli i w wytwory tych umysłów. Warto przypomnieć, co na temat ludzkich umysłów napisali Ian Stewart i Jack Cohen w Wytworach rzeczywistości:

Umysł nie jest niematerialną transcendencją: jest odpowiedzią rozwijającego się mózgu na konieczność przetrwania w złożonym środowisku. A wraz z ewolucją kultury to środowisko samo się zmienia i jest dla siebie odniesieniem; podobnie dzieje się z ludzkimi mózgami. Ewolucja i dostrajalne zmysły doprowadziły do powstania umysłów, które potrafią sobie radzić z rzeczywistością za pomocą cech, czyli struktur i procesów wyższego rzędu umiejscowionych w mózgu i odpowiadającym regularnościom o dużej skali, występującym w naszym otoczeniu?

Badacze ci w dalszej części tego tekstu stwierdzają także:

Nasze umysły ewoluują wspólnie ze wszystkim, co na nie wpływa. Umysły są wytworami rzeczywistości, procesami zachodzącymi w strukturach zbudowanych ze zwykłej materii, których właściwości rozwinęły się w celu naśladowania, kształtowania i wykorzystania procesów naturalnych. To tłumaczy, dlaczego są tak «nierozsądnie skuteczne» w postrzeganiu i reorganizowaniu swego środowiska. Los człowieka jest określany przez współdziałanie kultury i poszczególnych umysłów, które zarazem wzajemnie się kształtują ${ }^{8}$.

Niewątpliwie do wyróżników skutecznego wpływu mempleksu na ludzkie doświadczenia i wybory życiowe należy zaliczyć maksymalnie szeroki zakres aktywności, integralność czy wspólnotowość. W artykule Cykl życiowy memów ${ }^{9}$,

5 Tamże, s. 8.

${ }_{6}$ Przy opisie memów jako organizmów żywych przyjmujemy funkcjonalną definicję życia. Definiowanie funkcjonalne życia nie odwołuje się do struktury żywego organizmu, odnosi się do zdolności replikacyjnych organizmu oraz do wykazywania dziedzicznych zmienności. W takim ujęciu memy to byty wykazujące cechy organizmów żywych, zdolnych do replikacji i dziedzicznych zmienności, co skutkuje zdolnościami do ewoluowania. Rzecz jasna, należy zastrzec, że owe byty nie są świadome swojego życia i funkcji życiowych jakie z owego życia wynikają.

7 I. Stewart, J. Cohen, Wytwory rzeczywistości. Ewolucja umystu ciekawego, przeł. W. Stępień-Rudzka, Warszawa 2003, s. 8.

8 Tamże, s. 9.

9 H. Bjarneskans, B. Gronnevik, A. Sandberg, Cykl życiowy memótw, przeł. E. Jagt-Yazykowa, 
trzej szwedzcy badacze: Henrik Bjarneskans, Bjare Gronnevik i Anders Sandberg przyrównują cykl życiowy memów do cyklu życia pasożytów, dążąc do ustalenia stopnia zdolności przeżywalności memów. W podobny sposób możemy spojrzeć na cykl życiowy składowych mempleksu Norweskiego Snu, traktując je jako pasożyty ludzkiego umysłu.

\section{Morfologia Norweskiego Snu jako „mempleksu norweskości”}

Norwegian Dream rozumiany jako mempleks norweskości składa się z zespołu wspomagających się memów lokowanych w ludzkich aktywnościach dotyczących funkcjonowania organizacji współczesnego norweskiego świata oraz lokowanych w ludzkich reakcjach na te aktywności. Omówię te elementy cyklu życiowego memów wchodzących w skład mempleksu norweskości, które przyjmuję za charakterystyczne dla tego mempleksu. Na początku określić należy podstawowe pojęcia:

- Nosiciel/gospodarz. Nosicielami informacji kulturowych dotyczących funkcjonowania współczesnego norweskiego świata są wyłącznie ludzie, ściślej rzecz ujmując ich umysły, dla których warunkiem koniecznym owego nosicielstwa jest zdolność do kognitywnych refleksji nad przenoszonymi mempleksami.

- Wektor. Wektory opisać można jako „środki transportu” pomiędzy „kognitywnymi nosicielami”. Podstawową cechą wektorów jest brak zdolności kognitywnych dotyczących memów/mempleksów. Mówiąc wprost są to nośniki mempleksów. Rzecz jasna, człowiek także może być nośnikiem mempleksu Norweskiego Snu, jednak wyłącznie pod warunkiem braku refleksji kognitywnych z jego strony, bowiem zasada bezrefleksyjności wektora wobec mempleksu (który transportuje) jest konieczna.

- Świadomość. Mempleksy (podobnie jak memy, które wchodzą w ich skład) nie są świadome swojego życia i funkcji życiowych, jakie z tego faktu wynikają. Brak świadomości memów i mempleksów nie stanowi przeszkód dla ich reprodukcji i nie wpływa na fakt (i skuteczność) eksploracji konkretnego środowiska.

Analityczne ujęcie tekstu szwedzkich badaczy ukazuje że cykl życiowy memów należy odnieść do następującego schematu: kodowanie (tak w wektorze, jak i w nosicielu)/transmisja/dekodowanie/infekcja.

W fazie transmisji, mempleks jest kodowany do wektora jako zespół informacji, które należy przekazać. Norweski Sen znajduje szeroką globalną (lokowaną aktualnie na całym świecie) grupę nadawców i odbiorców. Użytkownicy mempleksu norweskości wpisuja się w tradycyjne kodowania, transmitowania i dekodowania. Na użytek tego tekstu, internet przyjmuję jako przykładowy i jedno-

w: Infosfera. Memetyczne koncepcje kultury $i$ komunikacji, wyb. i oprac. D. Wężowicz-Ziółkowska, Katowice 2009, s. 65-89. 
cześnie podstawowy wektor. Światowa sieć internetowa szczególnie dobrze sprzyja powstawaniu, utrzymywaniu i poszerzaniu grup użytkowników Norwegian Dream określonego przeze mnie jako mempleks norweskości, bowiem dzięki internetowi ludzkie umysły uzyskują globalny stopień kontaktu między członkami ponadnarodowej społeczności, możliwość współuczestnictwa i dostęp do aktualnej wiedzy na konkretne tematy, a finalnie uzyskują możliwość globalnego zespolenia. Wektor o globalnym zasięgu jakim jest internet, sprzyja również aktywnościom dotyczącym przekazywania informacji na temat koncepcji współczesnego norweskiego świata i praktycznej (można by powiedzieć: codziennej) realizacji tej koncepcji. Dzieje się tak dzięki używaniu nieskomplikowanego języka i lokowaniu przekazywanych informacji dotyczących praktycznych realizacji życia we współczesnej Norwegii w konkretnych a zarazem wiarygodnych kontekstach: społecznych, gospodarczych, politycznych czy geopolitycznych. Oto kilka przykładów. W trakcie przemówienia do narodu wygłoszonego przez premiera Norwegii, Jensa Stoltenberga w roku 2011, po masowym morderstwie, jakiego dokonał Anders Behring Breivik na wyspie Utoya, premier powiedział: „pochodniami i różami dajemy światu znak. Nie pozwolimy, by złamał nas strach. I nie pozwolimy, by strach nas zakneblował... [Naszą odpowiedzią jest] więcej otwartości, więcej demokracji. Niezłomność i siła.

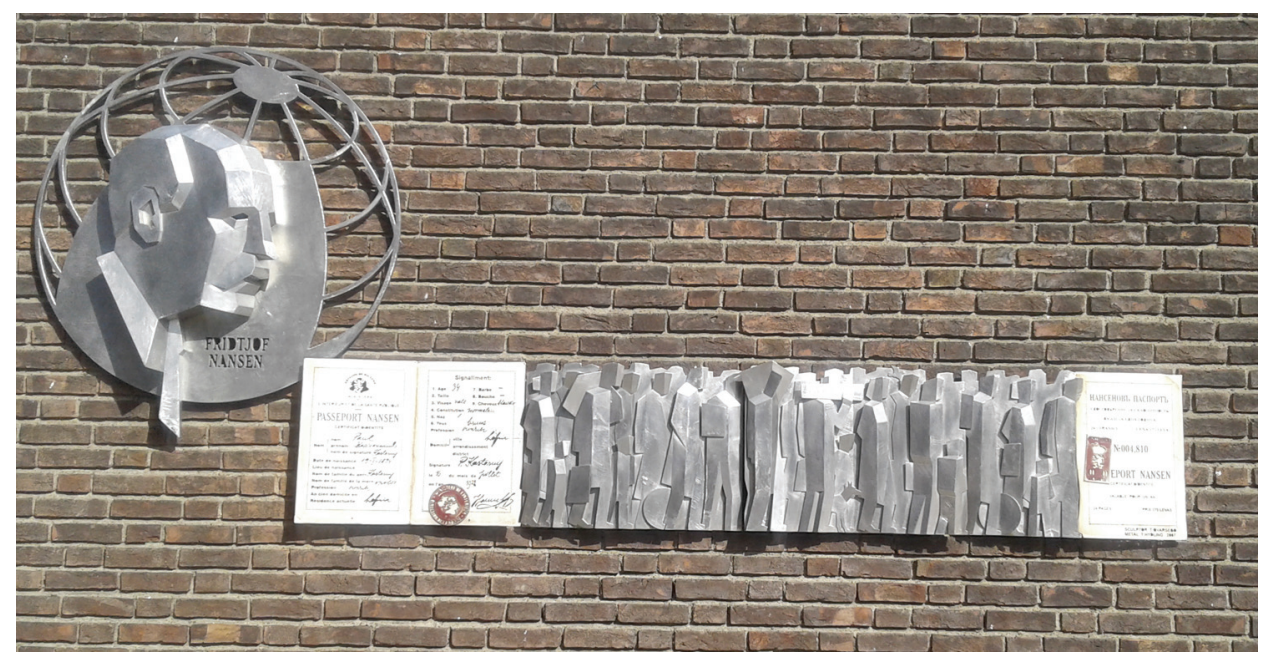

Fot. 1: Tablica pamiątkowa poświęcona Nansenowi umieszczona na placu Nansena w Oslo, lipiec 2019 r. (wszystkie fotografie w tekście mojego autorstwa - S.M.).

Oto my. Oto Norwegia”10. Warto przytoczyć także słowa norweskiej działaczki na rzecz pokoju Hildy Frafjord Johnson: „Centralne wartości, jak miłość bliźniego, poszanowanie dla ludzkiej godności i nasza odpowiedzialność za dzieło stworze-

10 N. Witoszek, Najlepszy kraj na świecie..., s. 144. 
nia, zobowiązują nas wszystkich, ponad granicami państw i wyznań"11 oraz stwierdzenie laureata Pokojowej Nagrody Nobla - Fridtjofa Nansena: „Rzeczy trudne robimy od ręki. Niemożliwe zajmują trochę więcej czasu"12.

I jeszcze słowa kolejnego byłego premiera Norwegii, Kjella Magne Bondevika:

Norwegia musi być narodem miłości bliźniego i solidarności. Idźmy w ślady Fridtjofa Nansena przez naszą ofiarność na rzecz uchodźców i cierpiących w innych krajach. Nasz naród daje teraz przykład innym, umarzając długi najuboższych krajów Trzeciego Świata. Norwegia jest w czołówce państw udzielających najwięcej pomocy. Marzymy, że nadejdzie kiedyś taki dzień, gdy żadne dziecko nie wyciągnie ręki po chleb - nie otrzymując go. Jeśli jesteśmy postrzegani jako Norwegia solidarna, Norwegowie mają powód do dumy ${ }^{13}$.

Wymowny jest także cytat z jednego z wielu artykułów prasowych, archiwizowanych i zdigitalizowanych na aktualnie dostępnych stronach internetowych dotyczacych praktycznego funkcjonowania koncepcji norweskiego ponowoczesnego świata: „Nicht der private, sondern der vergesellschaftete Reichtum ist es, der zahlt”14.

Wektor, jakim jest internet, umożliwia tanią, szybką i precyzyjną możliwość dotarcia memów/mempleksów do aktualnych i potencjalnych użytkowników norweskiej koncepcji organizacji współczesnego ponowoczesnego świata. Poszerzenie grup szczególnie przyszłych użytkowników norweskiego świata przekracza globalne granice przestrzenne i strefy czasowe, umożliwiając ciągłe docieranie do wszystkich użytkowników globalnej sieci internetowej. Mempleks, za jaki przyjmujemy Norweski Sen, replikuje się szybko, precyzyjnie docierając do grup docelowych, za które uważamy aktualnych i przyszłych (zdolnych do kognitywnych refleksji) nosicieli memów/mempleksów. W odniesieniu do struktur podstawową wartość tworzy spójność przekazu, która finalnie służy polepszaniu wierności kopiowania i zapobiega mutowaniu informacji kulturowych dotyczących organizacji i korzystania z norweskiego modelu współczesnego ponowoczesnego świata. Spójność przekazu przekłada się również na sprawniejsze transmitowanie mempleksów o zaawansowanych stopniach komplikacji, co znajduje praktyczne zastosowania przy transmisjach stopniowych. Przyjmuję, że wybór wektora, czy wektorów, jakie zostaną użyte, zależy od nosicieli. Nosiciele przeważnie korzystają z taniego, a zarazem precyzyjnego wektora, jakim jest przekaz informacji w internecie. Rzecz jasna dopiero dostęp do wielu wektorów i funkcjonowanie w wielu wektorach jednocześnie daje pewność przetrwania memom/mempleksom. Ważne jest to, żeby następowało wielokrotne przekazywanie informacji w sposób ciągły z wykorzystaniem różnych wektorów. Kodowanie do wektorów więcej niż jednej ko-

11 Tamże, s. 143.

12 Tamże, s. 178.

13 Tamże, s. 143.

14 Https://www.spiegel.de/spiegelwissen/deutsche-auswanderer-in-norwegen-karriere-und -kinder-a-885402.html [dostęp z dnia: 19.05.2019] (w tłumaczeniu autora tekstu: Nie prywatne, lecz uspołecznione bogactwo jest tym, co się liczy). 
pii i używanie więcej niż jednego wektora znacznie podwyższa sprawność (fitness) mempleksu. W tym przypadku funkcjonuje prosta zależność. Stałe zwiększanie ilości kopii robionych szybko i tanio oraz preferowanie strategii przekazu typu: wielu do wielu, skutecznie podwyższa sprawność mempleksu norweskości. Przepis na światowy sukces Norweskiego Snu sprowadza się do prostej zasady: wielość powtórzeń poprzez różnorodne wektory w jak najkrótszym czasie i bez ograniczeń przestrzennych. Rzecz jasna, przeżywalność mempleksu norweskości jest mierzona tak zwanym „trwaniem w czasie”. Zmienność sprowadza się do masowego korzystania z przybywających wektorów. Zdigitalizowane teksty pisane (teksty publikowanych książek/teksty artykułów/teksty przemówień itp.), zdigitalizowane wypowiedzi w mediach, zdigitalizowane zdjęcia czy filmy dotyczące mempleksu norweskości stają się wszechobecne, tak w nowoczesnych technologiach telefonii komórkowych, przekazach internetowych, jak w klasycznych nośnikach informacji jakimi są przykładowo: miejskie turystyczne tablice informacyjne czy punkty

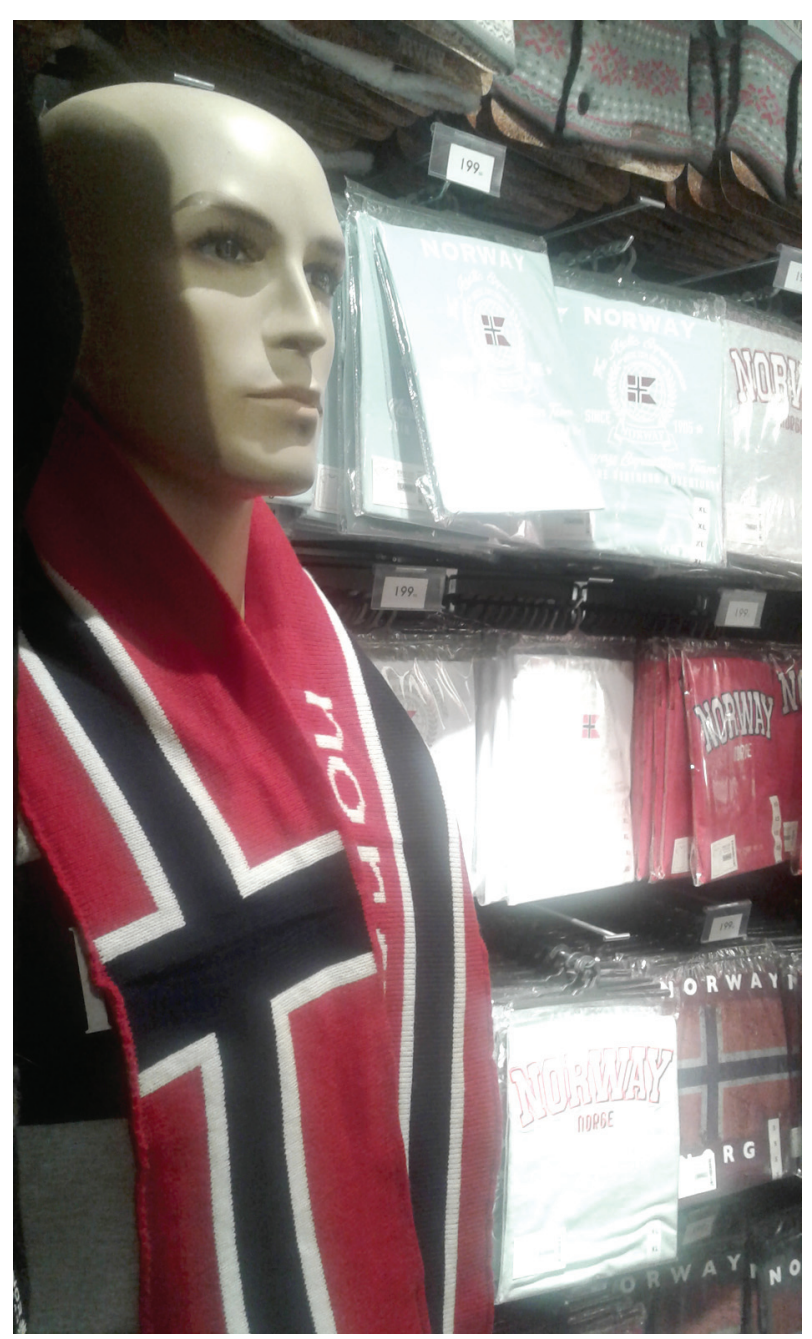
sprzedaży norweskich pamiątek (zawierających fragmenty tekstów pisanych czy slogany reklamowe, przykładowo: Norway - powered by nature). Dodajmy, nieprzypadkowo sklepy z tymi pamiątkami są zlokalizowane w najatrakcyjniejszych turystycznie i łatwo dostępnych (parter budynku handlowego w głównym ciągu komunikacyjnym norweskiego miasta) miejscach.

Fot. 2: Wnętrze sklepu z norweskimi pamiątkami w Karl Johans Gate w Oslo 


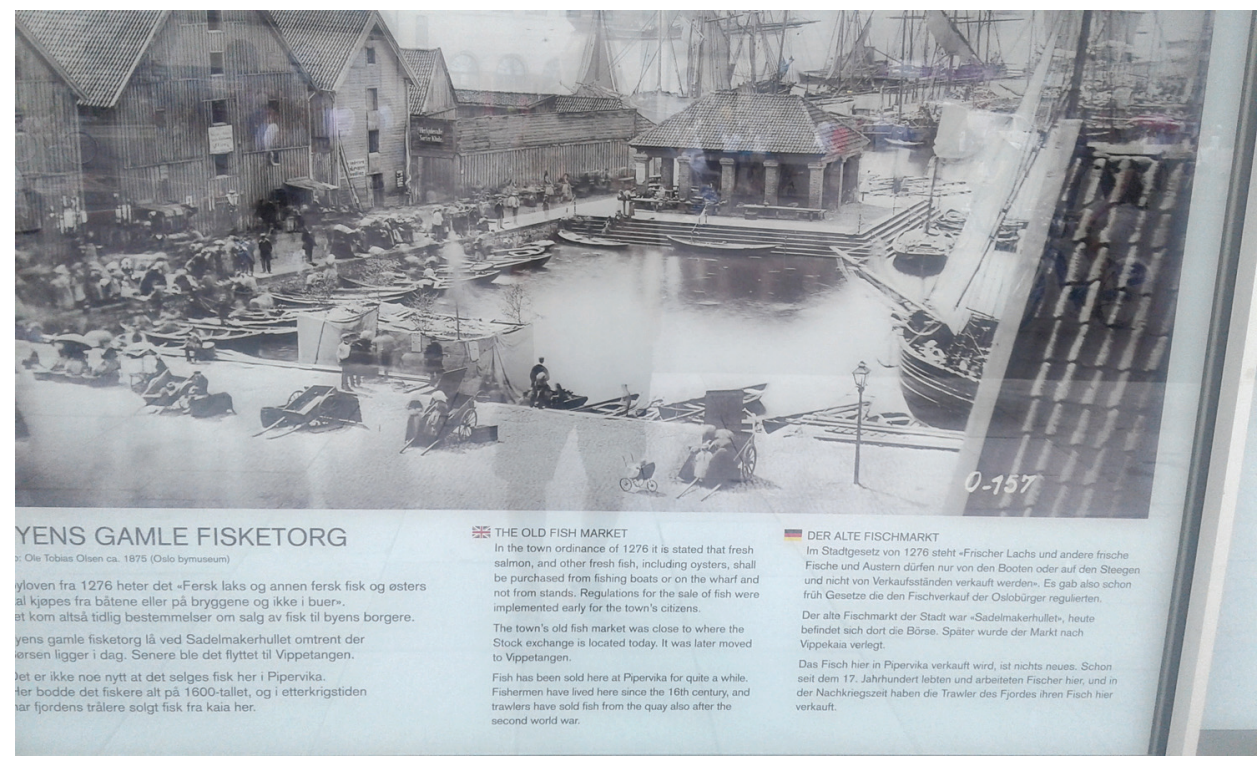

Fot. 3: Tablica turystyczna - Oslo lipiec 2019r.

\section{Accademia dell'Arcadia}

W fazie infekcji opisanej przez (wspomnianych powyżej) szwedzkich badaczy cyklu życiowego memów, wiele memów (a co za tym idzie: wiele mempleksów) uzyskuje znaczną skuteczność dzięki użyciu tak zwanych gróźb lub przynęt. W przypadku Norweskiego Snu szczególnie zauważalne są przynęty. Niewątpliwie przynętą stosowaną przez memy wchodzące w skład tego mempleksu są obietnice porządku publicznego czy sprawiedliwości społecznej dla każdego członka norweskiej społeczności. Można by rzec: dla stałych mieszkańców (lokatorów) i dla gości (sublokatorów) Królestwa Norwegii. Przynęty to: ponowoczesna koncepcja państwa dla obywateli realizowana w praktyce, klarowne planowanie bieżących potrzeb obywateli i realizacja wcześniej przyjętych społecznych prorodzinnych projektów społecznych. To zawsze transparentna i konsekwentna realizacja zaplanowanych projektów o charakterze społecznym. To również coś czego nie ma żaden inny kraj na świecie - charakterystyczne dla Królestwa Norwegii Kos, specyficzne norweskie zadowolenie ze społecznego bezpieczeństwa, przewidywalności społecznego ładu i porządku teraz i w przyszłości. Kos to właśnie taka przewidywalność dla wszystkich użytkowników (lokatorów/sublokatorów) norweskiego świata. Kos to, również, przynależności do konkretnie określonej społeczności, konkretnego pomysłu na państwo i na rolę tego państwa we współczesnym świecie. Mówiąc krótko: mentalny spokój na dziś i na jutro. Za kolejną przynętę można uznać korzyści finansowe dla obecnych i przyszłych pokoleń Norwegów jakie gwarantuje norweski fundusz naftowy - obecnie największy fundusz eme- 
rytalny na świecie. Przynętą jest niewątpliwie także praktycznie funkcjonujący, z rynkowymi sukcesami, skandynawski model gospodarki oparty na wspólnym działaniu gospodarki planowej z gospodarką rynkową. W końcu, przynętami sa wszelkie norweskie narracje dotyczące dobra, jakie tkwi w człowieku, a szczególnie jego praktycznych społecznych zastosowań - można by powiedzieć: od człowieka do człowieka. W zbiorowej norweskiej świadomości funkcjonuje słynna definicja narodowej kultury i tożsamości za jaką przyjęło się uważać słowa byłej premier Norwegii, Gro Harlem Brundtland: „dobroć to cecha typowo norweska” 15 . I jeszcze jedna przynęta: przynęta dobrostanu, składająca się z narracji, które nie opisują abstrakcyjnych wizji dobrobytu, opisują zaś praktyczne funkcjonowanie ludzi w ponowoczesnym norweskim społeczeństwie określanym jako: społeczeństwo dobrostanu ${ }^{16}$.

Warto zastanowić się czy za najbardziej spektakularną przynętę nie należy uznać odwołania do antycznego mitu arkadyjskiego, do dziś obecnego na całym świecie w ludzkich umysłach.

Dla starożytnych, mityczna Arkadia była uosobieniem ludzkiego szczęścia. Niewątpliwie, twórczość Owidiusza i Wergiliusza przyczyniły się do utrwalenia wizerunku Arkadii jako „oazy szczęśliwości”. Jest to przekonanie funkcjonujące w kulturze przez dwa tysiąclecia. Przekonanie że „gdzieś” istnieje miejsce/kraina w którym/ej panuje wyłącznie dobro, ludzie są względem siebie tolerancyjni i troskliwi, sprawiedliwość społeczna należy do standardów społecznego życia, zaś ludzkie szczęście jest powszechne. Wszyscy mieszkańcy żyją w intensywnym kontakcie z naturą, zajmując się pracą, po zakończeniu której mogą bez przeszkód spełniać się w gronie rodzinnym lub realizować osobiste pasje. Szczególnie dobrze znane w kulturze ikonograficzne przedstawienia idyllicznej ojczyzny ludzi szczęśliwych odnajdujemy tak w obrazie Guercina (ok. 1618, Rzym, Galleria Nazionale d'Arte Antica) jak i w wersjach Poussina (1627-1628, Chatsworth House; 1637-1638, Paryż, Luwr). To właśnie na tych obrazach malarze umieścili łacińską sentencję, której autorem jest prawdopodobnie rzymski poeta Auzoniusz: Et in Arcadia ego. Wyrażenie to miało charakter przesłania memento mori, przypominając o obecności śmierci również w Arkadii. Do mitu ludzkiej krainy szczęśliwości odwoływała się założona w Rzymie (w 1674 r.) Accademia dell'Arcadia, której celem było przeciwstawienie przepychowi panującemu na papieskim dworze zwykłego, skromnego życia. Współczesna Norwegia to nic innego: skromne życie w zgodzie z naturą. Kraina szczęśliwości, w której obecność ludzkiego cierpienia i ludzka śmierć nie są tematami tabu. Przestrzeganie praw człowieka, czynienie społecznego czy osobistego dobra, życie w pokoju znajdują się na porządku dziennym. Można by powiedzieć że Norwegian Dream to spełnienie (istniejącego od ponad dwóch tysięcy lat) ludzkiego pragnienia materializacji arkadyjskiego

\footnotetext{
15 N. Witoszek, Najlepszy kraj na świecie..., s. 22.

16 Tamże, s. 178.
} 
mitu w świecie, w którym żyjemy. Norweski Sen to materializacja arkadyjskiego mitu tu i teraz, we współczesnym ponowoczesnym norweskim świecie.

Niewątpliwie, globalna atrakcyjność propozycji „używania w życiu codziennym” norweskiej wizji współczesnego świata polega na tym, iż jest to praktyczna realizacja świata dla ludzi. Rzecz jasna, warto w tym miejscu zastanowić się nad tym, czy w tak rozumianym/opisanym norweskim świecie takie wartości, jak na przykład poszukiwanie piękna czy prawdy, ulegają zmianom, a nawet zapomnieniu? Warto też zastanowić się nad tym, czy w narracjach wchodzących w skład Norwegian Dream, przyczyniających się do tworzenia, utrzymania i rozwijania wizji norweskiego ponowoczesnego kraju rozumianego jako aktualnie najlepszy „do życia” ze znanych współczesnemu człowiekowi krajów na świecie, nie powinna pojawić się refleksja dotycząca kosztów realizacji takiej wizji świata i kosztów planowania przyszłości dla takiej wizji świata. Jeśli ma to być świat bez poszukiwania prawdy i piękna, to finansowa niezależność współczesnej Norwegii czy zaplanowana finansowa niezależność dla przyszłych pokoleń Norwegów niekoniecznie jest/staje się wartością, na której należy budować model świata dla przyszłych norweskich pokoleń i jednocześnie ukazywać Norwegię jako najlepsze miejsce „tu i teraz” dla (prawie) każdego człowieka na naszej planecie.

Fot. 4: Współczesny poszukiwacz norweskiego dobrostanu, Oslo, lipiec 2019.

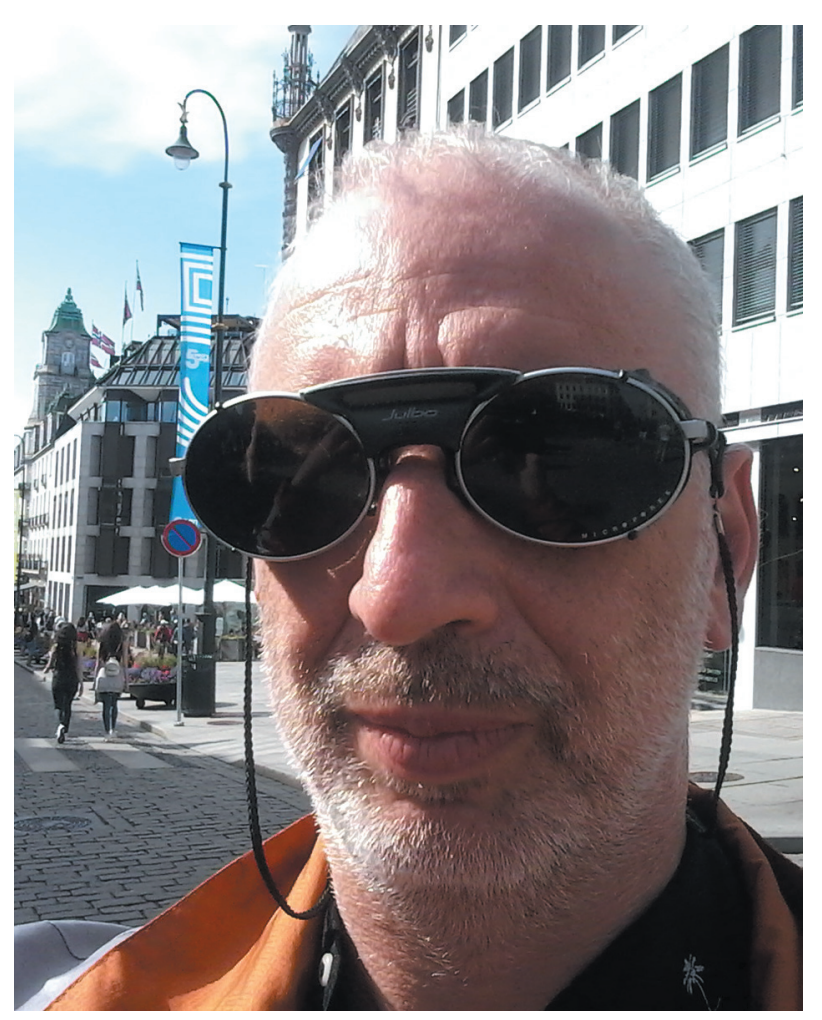


W tym miejscu przypomina się zdanie autorstwa Freda Inglisa:

Jednak najbardziej ponurą wizją byłoby przypuszczenie, że przetrwawszy najbardziej przepełniony śmiercią XX wiek, nauczyciele najnowszej generacji, promieniując jak ich poprzednicy radością i nadzieją, mogliby powiedzieć swoim dzieciom, że wszystko jest stracone: że zostały stracone kultura, piękno i prawda, a jedyne, co mogą im zaoferować, to pieniądze ${ }^{17}$.

Przypomnę na koniec znaną sentencję/mem: „pieniądze to nie wszystko”. Istnienie świata „bez pieniędzy” jest wyobrażalne i (niestety) praktycznie możliwe. Wyobrażalny jest również świat, w którym „coś” nie musi być zamiast „czegoś innego” lub przeciw „czemuś innemu”.

Warto, w tym miejscu, zastanowić się, o jakim modelu współczesnego kraju myślał Hans Magnus Enzensberger, określając miejsce Norwegii w Europie jako: „olbrzymie laboratorium przyszłości”18.

\section{BibliografiA}

Atran S., Ewolucyjny krajobraz religii, przeł. M. Kolan, Kraków 2013.

Baggott J., Pożegnanie z rzeczywistością. Jak wspótczesna fizyka odchodzi od poszukiwania naukowej prawdy, przeł. M. Krośniak Warszawa 2015.

Bjarneskans H., Gronnevik B., Sandberg A., Cykl życiowy memów, przeł. E. Jagt-Yazykowa, w: Infosfera. Memetyczne koncepcje kultury i komunikacji, wyb. i oprac. D. Wężowicz-Ziółkowska, Katowice 2009, s. 65-89.

Blackmore S., Maszyna memowa, przeł. N. Radomski, Poznań 2002.

Blumenberg H., Rzeczywistości w których żyjemy, przeł. W. Lipnik, Warszawa 1997.

Brodie R., Wirus umystu, przeł. T. Turski, Łódź 1997.

Casacuberta D., Umyst. Czym jest i jak działa, przeł. J. Krzyżanowski, Warszawa 2007.

Damasio A., Btad Kartezjusza. Emocje, rozum i ludzki mózg, przeł. M. Karpiński, Poznań 2013.

Damasio A., Jak umyst zyskat jaźń. Konstruowanie świadomego mózgu, przeł. N. Radomski, Ponań 2011.

Dawkins R., Fenotyp rozszerzony. Dalekosięzny gen, przeł. J. Gliwicz, Warszawa 2003.

Dawkins R., Samolubny gen, przeł. M. Skoneczny, Warszawa 1996.

De Pascale E., Śmierć i zmartwychwstanie, przeł. A. Kłos, Warszawa 2011.

Dennett D.C., Dźwignie wyobraźni i inne narzędzia do myślenia, przeł. Ł. Kurek, Kraków 2015.

Dennett D.C., Odczarowanie. Religia jako zjawisko naturalne, przeł. B. Stanosz, Warszawa 2013.

Dennett D.C., Natura umystów, przeł. W. Turopolski, Warszawa 1997.

Enzensberger H.M., Utwory wybrane, przeł. J.S. Buras, A. Kopacki, Kraków 2001.

Kołakowski Leszek: Czy diabet może być zbawiony i 27 innych kazań, Londyn 1984.

Kołakowski L.: Horror methaphysicus, przeł. M. Panufnik, Warszawa 1990.

Nietzsche F., Ecce homo, przeł. B. Baran, Kraków 1995.

Pinker S., Tabula rasa. Spory o naturę ludzka, przeł. A. Nowak, Sopot 2012.

Różewicz T., Poezje wybrane, Kraków 1991.

Schopenhauer A., O wolności ludzkiej woli, przeł. A. Stogbauer, Kraków 2014.

17 F. Inglis, Kultura, przeł. M. Stolarska, Warszawa 2007, s. 212.

18 H.M. Enzensberger, Norsk utakt, Oslo 1976. 
Schwarz F., Dlaczego myślimy to, co myślimy. Wzorce w gtowie, przeł. M. Dutkiewicz, Warszawa 2007. Searle J.R., Umyst. Krótkie wprowadzenie, przeł. J. Karłowski, Poznań 2010.

Shermer M., Rynkowy umyst. Empatyczne matpy, konkurujacy ludzie i inne opowieści ekonomii ewolucyjnej, przeł. A.E. Eichler, P.J. Szwajcer, Warszawa 2009.

Spitzer M., Jak uczy się mózg, przeł. M. Guzowska-Dąbrowska, Warszawa 2012.

Stewart I., Cohen J., Wytwory rzeczywistości. Ewolucja umystu ciekawego, przeł. W. Stępień-Rudzka, Warszawa 2003.

Wężowicz-Ziółkowska D., Moc narrativum. Idee biologii we wspótczesnym dyskursie humanistycznym, Katowice 2008.

Wilson E.O., O naturze ludzkiej, przeł. B. Szacka 1988.

Wiśniewska I., Hen, Wołowiec 2016.

Witoszek N., Najlepszy kraj na świecie. Pamflet, przeł. M. Kalinowski, Wołowiec 2017.

\section{Nota o autorze}

Stanisław Masłowski - absolwent kulturoznawstwa Uniwersytetu Śląskiego w Katowicach, doktorant w Zakładzie Teorii i Historii Kultury INoKiSI. Zainteresowany wykorzystaniem memetyki do obserwacji i badań współczesnej kultury. Jest zwolennikiem praktycznego zastosowania neurowiedzy w gospodarce i życiu społecznym.

\section{About the author}

Stanisław Masłowski - graduate of cultural studies at the University of Silesia in Katowice. A Ph.D. student in the Department of Theory and History of Culture, at the University of Silesia in Katowice, Institut of Cultural Studies and Interdisciplinary Studies. Interested in application memetics in observations and research of contemporary culture. Supporter of using neuroscience in economy and social life. 